\title{
Comparison of Household and Communal Biogas Digester Performance to Treat Kitchen Waste, Case Study: Bandung City, Indonesia
}

\author{
Elisabeth Rianawati ${ }^{1, *}$, Enri Damanhuri ${ }^{2}$, Marisa Handajani $^{2}$ and Tri Padmi $^{2}$ \\ ${ }^{1}$ Resilience Development Initiative, Bandung - Indonesia \\ ${ }^{2}$ Department of Environmental Engineering, Faculty of Engineering, Institute Teknologi Bandung - Indonesia
}

\begin{abstract}
Bandung City is one of the big cities in Indonesia that grappled with waste problem. There is 1,500 ton of waste produced daily, of which $65 \%$ is organic. In addition, the water content of the waste could reach $80 \%$ during rainy season, given that the waste is commonly collected in open space before transported to the final disposal area. In order to tackle this issue, the municipality of Bandung has started to implement anaerobic digesters to treat kitchen waste since 2013 in an attempt to reduce organic waste. There are three scales of bio-digesters that have been implemented: city ( 2 ton), communal (20-1000 kg) and household scale $(20 \mathrm{~kg})$, which comprise of 1 unit, 15 units and 100 units respectively. This study evaluate the efficiency and biogas productivity of each bio-digesters type. We analyzed 30 unit and 14 unit of household and communal biodigesters respectively. The waste input, slurry output and biogas production were estimated based on average of daily basis. Both the input and output of the biodigesters were characterized (TS, VS, COD) to gain further understanding. This study provide facts and figures to improve the further implementation of household bio-digesters in Bandung City.
\end{abstract}

Keywords: biodigester, household scale, communal scale, kitchen waste, efficiency.

\section{Introduction}

Anaerobic microbes are known to be able to breakdown organic matter into biogas [1]. This conversion technology has contributed several health and environmental advantages like better sanitation, effective waste management, greenhouse emission mitigation and sustainable energy generation [1].

To tap these benefits, anaerobic digestion has been broadly implemented in Bandung City [2]. BPLH of Bandung City estimated that in 2017, Bandung City generates 1,881 ton of waste per day and food waste accounted for $45,1 \%$ of it [3]. Kitchen waste is one the main component of municipal waste, and has putrescible nature. However, it can produce high biogas yields from its degradation in anaerobic digestion under appropriate operation [4]. In Bandung City, there are three scales of bio-digesters that have been implemented: 1 unit of city scale digester (2 ton) [5], 15 units of communal scale digester $(20-1000 \mathrm{~kg})$ and 100 units of household scale digester $(20 \mathrm{~kg})$ [6].

There are two types of household scale biodigester based on their brands, namely BSO-15 and BioMethaGreen. BSO-15 has a sylindrical shape with $100 \mathrm{~cm}$ diameter and $160 \mathrm{~cm}$ height. On 2015, 100 units of BSO-15 was given to Bandung City Government under a corporate social responsibility scheme. BioMethagreen was developed based on mixed plug flow loop (MPFL) system and has a box shape with 200 $\mathrm{cm}$ length, $100 \mathrm{~cm}$ width and $100 \mathrm{~cm}$ height.

Unfortunately, almost all the anaerobic digester implemented faced severe challenges in its daily operation. One of the examples was the city scale digester located in Gedebage which has stopped operating since February 2016, prior functioning for only two months [7]. Thus, this paper is written to analyze the feasibility of biodigester application in Bandung city. The feasibility study will be assessed from the hydraulic retention time (HRT), volatile solids (VS) reduction, total solids (TS) reduction and chemical oxidation demand (COD) reduction. It is expected that the findings of this study can be useful for the development of biodigesters in particular and development of low carbon society in general.

\subsection{Communal scale biodigester}

The communal biodigester is BioMethaGreen brand which has feed requirement of $250 \mathrm{~kg} /$ day with $10 \mathrm{~m}^{3}$ capacity and are able to produce biogas $4-6 \mathrm{~m}^{3} /$ day. BPLH of Bandung City estimated the amount of city waste treated using biodigester using 14 communal scale digesters is $0.23 \%$ which is still below the target of $1 \%$ [3]. Out of 9 biodigesters only 3 were in operation, whereas 6 were not in use due to various reasons, which include lack of manpower to operate biodigester, flood,

* Corresponding author: erianawati@gmail.com 
lack of incentive to keep the workers going and poor maintenance by the operators which has resulted into inapproporiate operation, poor performance and segregation and damage of biodigester. Two of the biodigesters produced between 0.23 and $0.45 \mathrm{~m}^{3} /$ day based on burning time $30-60$ min (assuming biogas gas consumption rate of $0.45 \mathrm{~m}^{3} / \mathrm{h}$. However, which actually rely on several factors such as the country and its economic growth etc.) [1].

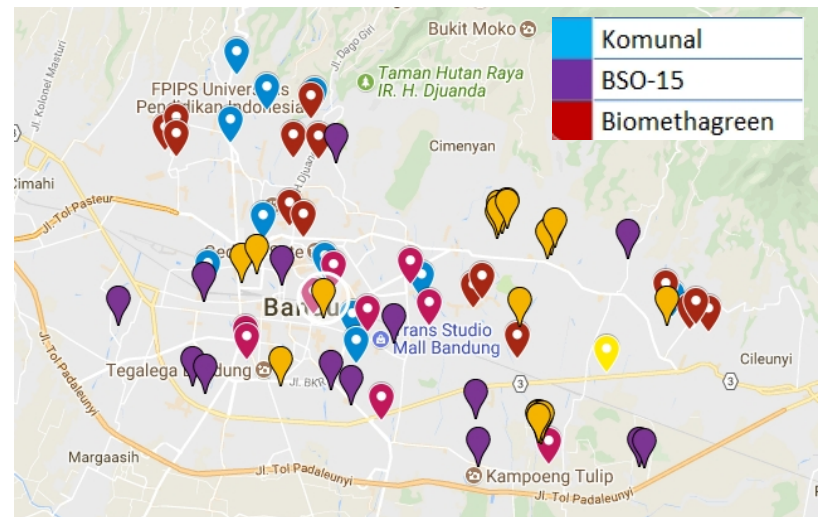

Figure 4. Lokasi survei AD skala rumah tangga (BSO-15, biomethagreen) dan komunal di Kota Bandung

Institutional digesters $\left(5-25 \mathrm{~m}^{3}\right)$ produced biogas between 3.07 and $6.13 \mathrm{~m}^{3} /$ day which equates to approximately 6 h $49 \mathrm{~min}-13 \mathrm{~h} 37 \mathrm{~min}$ of continuous burning on a single household stove. However, there are not many performance data for digesters for this size range with food waste as substrate. Thus to compare digesters of similiar scale, this study considers similiar scale institutional digesters utilizing food waste and mixed manure. For instance, a bigger digester of $8-10 \mathrm{~m}^{3}$ fixed Chinese dome that was fed with a mixture of black water, piggery waste, fruit and vegetable waste produced between 0.3 and $0.9 \mathrm{~m}^{3} /$ day of biogas [8] whereas in Vietnam, a $5 \mathrm{~m}^{3}$ polyethylene digesters produced 1.23 $\mathrm{m}^{3}$ biogas/day fed from $1.16 \mathrm{~kg} \mathrm{VS} /$ day [9].

\subsection{Household scale biodigester}

The bio gas in the biomethagreen biodigester will form 4-7 days after the waste is inserted. This digester is designed to produce 12-40 liters of biofuel from every 1 $\mathrm{kg}$ of organic waste [3].Water is required $20 \%$ of the amount of organic waste; stirring is recommended every 3 days, where one cubic meter $(1 \mathrm{~m} 3)$ of biogas is equivalent to cooking for family purposes for 3 hours [10].

Out of 40 biodigesters only 30 were in operation, whereas 10 were not in use due to various reasons, namely insufficient operating instructions and training given by the distributor, which has led to low understanding on the way biogas systems should be operated; insufficient amount of waste; and the biodigester unit is broken.

\section{Material and Methodology}

This study applied different methods used to collect a snapshot of the individual biodigesters performance. To determine the field performance of the household scale biodigesters, influent and effluent samples from two BioMethaGreen units were analyzed. Both digesters are single phase digesters with no insulation and heat regulators.

\subsection{Biogas production and feed characteristics}

Feed of anaerobic digestion were determined by weighing daily waste using a spring weighing scale (maximum load $5 \pm 0.02 \mathrm{~kg}$ ). The food waste was visually inspected for the compositions of food waste. Effluent and feed samples were collected for parameter analysis by using one liter sample. Design analysis using theoretical biomethane potential (BMP) and actual $\mathrm{CH}_{4}$ volume calculation are used to obtain the amount of methane produced.

The maximum methane potential was based on approximation of COD concentration and was calculated using Eq. (1), supposing that this formula is valid for any product or substance [11]. This formula is based on the theoretical value of methane production at laboratory conditions:

$$
B M P_{\text {thcod }}=\frac{n_{\mathrm{CH}_{4}} R T}{p V S_{\text {added }}}
$$

where $\mathrm{BMP}_{\text {thCOD }}$ is the theoretical methane production at laboratory conditions, $T$ is the glass bottle temperature (308 K), $R$ is the gas constant $\left(R=0.082 \mathrm{~atm} \mathrm{~L} \mathrm{~mol}^{-1} \mathrm{~K}^{-}\right.$ $\left.{ }^{1}\right), \quad p$ is the atmospheric pressure (1 atm), $n_{\mathrm{CH}_{4}}$ is the amount of molecular methane (mol) calculated from Eq. (2) and $\mathrm{VS}_{\text {added }}$ are the substrate volatile solids (g) and [12].

$$
n_{\mathrm{CH}_{4}}=\frac{C O D}{64\left(\frac{g}{m o l}\right)}
$$

\subsection{Chemical analysis}

The effluent and food waste collected at each site were tested for organic-C, total solids (TS), total chemical volatile solids (VS) and oxygen demand (COD). Within 1 week of collection, samples were tested at Environmental Engineering water laboratory in Bandung Institute of Technology (ITB), Indonesia according to Standard Methods.

\section{Results and Discussion}

\subsection{Reduction of waste volume and organic loading}




\subsubsection{Communal scale}

The daily waste reduction can be quantified by comparing TS concentration of the influent with that of the effluent. To describe the reduction of organic load, one option is to measure the VS of influent and effluent. Another alternative to measure the reduction in organic load is through COD [13].

From the comparison of influent and the effluent characteristics, it can be seen that the COD were degraded significantly to less than $35,000 \mathrm{mg} / \mathrm{L}$ in the digester (Table 1). The effluent concentration had the lowest concentration of $12,320 \mathrm{mg} / \mathrm{L}$ which was far exceed the effluent standard for release into the environment $(150 \mathrm{mg} / \mathrm{L})$. The regulation applied to the effluent quality standard of biodigester is Regulation of Environment Minister Number 5 Year 2014 Appendix XIII, that is Wastewater Quality Standards for Business and/or Processing Activities of Fruits and/or Vegetables.

Both household and communal digesters reduced over $29 \%$ for COD concentrations, between $68 \%-85 \%$ for TS concentration and between $82 \%-92 \%$ for VS concentration (Table 1). This depicted the ability of both the household and communal digesters for mass removal, substrates degradation, and biogas production.

Compared to the results obtained by Voegeli et al. [13], the COD reduction is relatively low (83\%); the TS reduction is almost equal $(72.8-85.3 \%)$; and the VS reduction is also almost equal (85.3-92.2\%).

Table 1. Chemical characteristics of influent and effluent

\begin{tabular}{|c|c|c|}
\hline Parameter & Household & Communal \\
\hline \multicolumn{3}{|l|}{ COD } \\
\hline Influent (mg/L) & 55,680 & 23,680 \\
\hline Effluent (mg/L) & 34,090 & 12,320 \\
\hline COD reduction $(\%)$ & 29.89 & 47.97 \\
\hline \multicolumn{3}{|l|}{ TS } \\
\hline Influent (mg/L) & 44.89 & 76.09 \\
\hline Effluent (mg/L) & 14.28 & 11.51 \\
\hline TS reduction (\%) & 68.18 & 84.87 \\
\hline \multicolumn{3}{|l|}{ VS } \\
\hline Influent (mg/L) & 51,648 & 70,713 \\
\hline Effluent (mg/L) & 9,056 & 6,168 \\
\hline VS reduction $(\%)$ & 82.47 & 91.28 \\
\hline
\end{tabular}

\subsection{Gas production}

BMP method is used to measure the ability of the substrate to produce methane.

Table 2. Theoretical gas production

\begin{tabular}{|l|r|r|}
\hline & Household & Communal \\
\hline$n_{\mathrm{CH}_{\perp}}(\mathrm{mol} / \mathrm{L} \mathrm{COD})$ & 0.87 & 0.37 \\
\hline $\mathrm{BMP}_{\text {thCOD }}(\mathrm{L} / \mathrm{g} \mathrm{VS})$ & 0.427 & 0.132 \\
\hline
\end{tabular}

Nielfa et al. [12] obtained $\mathrm{BMP}_{\text {thCOD }} 0.536 \mathrm{~L} / \mathrm{gVS}$ for OFMSW co-digested with sludge, yet for the experiment results the BMP was $0.202 \mathrm{~L} / \mathrm{gVS}$, less than half of the results of theoretical calculation.

The significant difference between the theoretical and experimental results may be affected by several inhibitors, one of which is ammonia, which is formed from the nitrogenous degradation. The nitrogenous matters were mostly found in the form of proteins and urea [14]. With increasing levels of ammonia-N the digestion process would be inhibited [15]. The ammonia inhibition could be reduced through $\mathrm{C} / \mathrm{N}$ ratio adjustment of the feedstock and dilution of digester contents with water[16].

Based on the conducted interviews, the biogas stove usage per day is between 20-60 minutes, which is equivalent to biogas production of $0.15-0.45 \mathrm{~m}^{3} / \mathrm{day}$, assuming that the biogas gas consumption rate was 0.45 $\mathrm{m}^{3} / \mathrm{h}[13]$.

Both biodigesters were never emptied, thus the HRT is 9 months. In Climenhaga [17] study, the 100-day HRT reactors maintained the total ammonia nitrogen (TAN) levels beyond $3 \mathrm{gl}^{-1}$, whereas the higher HRT period of 180-day, the TAN value exceeded $5.7 \mathrm{gl}^{-1}$ at pH above 7.5. Based on Kaparaju and Rintala [18] study, free ammonia which exceeds $1000 \mathrm{mgl}^{-1}$, beyond the treshold of $3000 \mathrm{mgl}^{-1}$ would severely inhibit methane production[19]. Nonetheless, in this study, as the substrate had extended HRT time of 9 months, TAN exerted more beneficial effect to methane production than detrimental, compared to the 25-day HRT reactors. In shorter HRT reactor, TAN is washed out and declines through the trial [17].

The production of biogas is irregular and not continuous due to the inconcistency of the feed input.

\subsection{Survey of biogas systems}

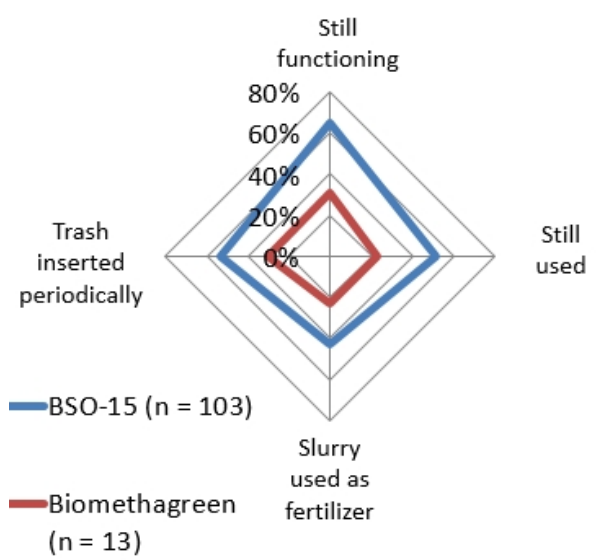

Figure 4. Household biodigesters survey result

The household survey conducted revealed that out of 40 biodigesters only 30 were in operation, whereas 10 were not in use due to various reasons, which include:

- Insufficient operating instructions and training given by the distributor, which has led to low understanding on the way biogas systems should be operated; 
- Poor maintenance by the operators, which has resulted into inappropriate operation, poor performance and damage of biodigesters;

- Insufficient amount of organic waste being fed into the biodigesters; and,

- Lack of follow-up services by the distributors, which largely been responsible for failures of biodigesters for unidentified reasons.

In some cases, the digester was not in use for several months and the real cause of the failure could not be determined. Other digesters that were still in operation also faced various problems, namely:

- Overloading;

- The gas did not come out of the gas outlet pipe or have enough pressure;

- The gas smelled sulphuric;

- The stove was rusty and clogged; and etc.

Considering the fact that even minor problems can lead to a complete failure of the system (e.g. blockage of the gas pipe due to condensation of water in the pipe), proper training and effective follow-up services are inevitable for the sustainability of the biodigesters [13]. Based on these observations, following improvement proposals are given:

- Routine follow-up services by technicians, especially during the first few months after installation of biodigester until the users are able to operate and do minor maintenance of the systems independently on a daily basis;

- Preparation of a simple manual in Bahasa for customers which contain information on operating the system (notably the feeding procedure) and trouble shooting;

- The distributors are responsible to determine which households are needed to dispose of their organic waste to a particular biodigester, in order to obtain sufficient amount of waste for a biodigester; and

- Install a simple water drain to regularly remove water condensed in the pipes.

\section{Conclusion}

The communal and household biodigests have not been efficient because they have high HRT and low performance. In general, Biomethagreen has a better performance because it has a low service life. Household biodigesters have higher OLRs than urban and communal scales, due to good waste sorting and more regular feed frequency.

From the observation of three scales of biodigester performances, the household scale is the most feasible to be implemented because the kitchen waste is segregated from the source and the amount of waste needed is small. However, regular follow-ups and training is needed to ensure the sustainability of the biodigesters.

\section{References}

1. X.F. Lou, J. Nair, G. Ho, ENERGY SUSTAIN DEV 16, 509-514 (2012)

2. Perdana, P. P. (2015). Polemik Soal Sampah, Ridwan Kamil Tawarkan Biodigester - Nasional Tempo.co. Retrieved October 31, 2017, from https://nasional.tempo.co/read/688871/polemiksoal-sampah-ridwan-kamil-tawarkan-biodigester

3. BPLH Kota Bandung, LAPORAN AKHIR Kajian Potensi Timbulan Sampah Kota Bandung, (2016)

4. H.N. Chanakya, I. Sharma, T.V. Ramachandra, Waste Manag 29, 1306-1312 (2009)

5. Dipa, A. (2015). Bandung to use biodigester in waste-based power plant - National - The Jakarta Post. Retrieved November 2, 2017, from http://www.thejakartapost.com/news/2015/08/06/ba ndung-use-biodigester-waste-based-powerplant.html

6. Soemitro, M. G. (2017). "Quo Vadis" Perkembangan Biodigester Sampah di Kota Bandung oleh Maria G Soemitro Kompasiana.com. Retrieved November 2, 2017, from

https://www.kompasiana.com/mariahardayanto/59d 4d97c0c8f2d4fb648ac82/quo-vadis-perkembanganbiodigester-sampah-di-kota-bandung

7. Instalasi Biodigester Pasar Gedebage Butuh Perbaikan I PD Kebersihan Bandung. (2016). Retrieved November 2, 2017, from http://pdkebersihan.bandung.go.id/index.php/2016/0 8/07/instalasi-biodigester-pasar-gedebage-butuhperbaikan/

8. W. van Groenendaal, W. Gehua, Energy 35, 44574466 (2010)

9. B.X. An, T.R. Preston, F. Dolbreg, LIVESTOCK RES RURAL DEV 9, 2 (1997)

10. M.F. Wiyatna, Biomethagreen Guidebook, 2009

11. D. Tarvin, A.M. Buswell, J. Am. Chem. Soc. 56, 1751-1755 (1934)

12. A. Nielfa, R. Cano, M. Fdz-Polanco, Biotechnol Rep (Amst) 5, 14-21 (2015)

13. Y. Voegeli, C. Lohri, G. Kassenga, U. Baier, C. Zurbrügg, Proceedings Sardinia Margherita Di Pula, (2009)

14. M. Kayhanian, J Chem Technol Biotechnol 59, 349-352 (1994)

15. Y. Chen, J.J. Cheng, K.S. Creamer, Bioresour. Technol. 99, 4044-4064 (2008)

16. M. Kayhanian, Environ Technol 20, 355-365 (1999)

17. P. Kaparaju, J. Rintala, RESOUR CONSERV RECY 43, 175-188 (2005)

18. I. Angelidaki, B.K. Ahring, Appl. Microbiol. Biotechnol. 24, 102-105 (1993)

19. M.A. Climenhaga, Water Sci. Technol 57, 687-92 (2008) 